\title{
On document supply in the digital world
}

Joachim Schöpfel, Jacqueline Gillet

INIST-CNRS, 2 allée du Parc de Brabois, F-54519 Vandœuvre-lès-Nancy Cedex.

\begin{abstract}
Purpose: The article provides insight into the evolution of document supply from traditional print copy delivery to a modern service of resource discovery and secure electronic supply.

Approach: The study is based on evidence from empirical data at INIST, as well as inquiries and case studies from other suppliers and customers.

Findings: Four topics are presented: the customers' needs, the use of new technologies in the front- and back-office, resource sharing and networking on the national and international level, and the negotiation of copyright agreements with publishers.
\end{abstract}

Originality: Based on evidence, an overall synthesis is given on significant developments, providing outlines of the future of document supply.

\section{Keywords}

Document supply, customer needs, information system, networking, resource sharing, copyright, electronic delivery, scientific and technical information.

\section{Paper type}

Conceptual paper.

\section{Introduction and issues}

Earlier this year major national STI centres ${ }^{1}$ met STM publishers and associations in London. ${ }^{2}$ This ICSTI ${ }^{3}$ roundtable aimed to develop mutual understanding and explore cooperation in preservation, licensing and supply of scientific information. One of the questions concerned the role of STI centres in the digital world.

The discussion revealed that this role was not clear. The STI centres see their fundamental roles remaining unchanged in the digital age: they collect, catalogue, and organize information and with respect to e-journals, require the right to locally host, store, preserve and disseminate digital documents in perpetuity, allowing free access to this material for private study as well as for non-commercial research.

\footnotetext{
${ }^{1}$ The British Library, CISTI, TIB Hannover, INIST, VINITI, Library of Congress, NLM, DTIC, ISTIC, KISTI, VTT Information Service.

${ }^{2}$ See the minutes at http://www.icsti.org/ICSTI-Publishers-19Jan2007_Summary Report_Final_e.do

${ }^{3}$ International Council for Scientific and Technical Information
} 
For the publishers, nothing is as before: their aim is to negotiate licences that enable end users access combined with pay-per-view. Whereas the historical functions of STI centres are being taken over either by the scientific communities - academic consortia, universities, research organisations - or by the publishers or vendors themselves.

Document supply is one of the main activities of national STI centres. Now, which of the above perspectives is most accurate in the digital world? A lot has been said and written, especially in this journal, about the decreasing demand, the growing access to digital resources through portals and open archives, about the serials' price crisis and the debate on new business models, and on the impact on traditional document supply services (see in particular Baker 2003, Brown 2003 and Rowse 2003).

We won't add another detailed analysis of what is already known by the informed reader. Instead, we will look at some empirical evidence on key aspects of document supply and provide some ideas of what could be a modern document supply service of national STI centres in future.

\section{A customer-centred service}

Modern document supply is customer-centred, not service-centred. The end-users' behaviour and needs count, not the preservation of redundant models of production, organisation and business. What do customers want?

The whole range of information: Customers of document supply want to get all information they need for their fundamental or industrial research and development. They don't want to be limited by collections, laws or technical barriers. The whole range of information means: print material as well as online resources, commercial products, grey literature, resources in open archives and institutional repositories, hidden digital stuff in the emerging Web2.0 environment, data sets etc.

Valuable information: Customers want high quality information without worrying about non revised stuff. They have a strong preference for content that has undergone peer review (Beckett and Inger 2006) and want value for money, not a lot of online material they have to sort or evaluate themselves. Unselected material and information overload are characteristics of free online searching, not of document supply that has to provide some added value.

Simple discovery: Customers want a quick and unsophisticated way to information. They need powerful and intuitive search tools instead of complicated, "professional" library-centred software. These search tools should cover the whole range of information, not only some segments. The whole range of information includes the customers' own resources - if there are any- in order to rationalize discovery and to limit multiple, complicated or redundant search strategies.

Simple ordering: Customers want an easy-to-use interface with a rapid "clickthrough" ordering of material. They don't want to type or paste item references into a separate order template. Items and item files should be imported directly from the search tool into the document supply system, without functions other than simple customer identification and/or online ordering information.

Timeliness: In the digital world customers want instant, unmediated access to the information they pay for. Short and guaranteed delays ( 24 or 48 hours) are acceptable 
if the price is low (hard discounting) but longer delays aren't or only if there are explicit reasons. At any moment, customers want feedback on the order processing.

Legal compliance: Customers don't want to worry about legal aspects. Document supply must be $100 \%$ compliant with national and international laws, and customers must be sure that the information they paid for has been legally acquired. Legal barriers by national laws and other restrictions need explanation.

Control: Corporate companies especially, but also academic libraries and research organisations want control of their orders, statistical reports of who ordered how many items, and sometimes even of the supplied content (serials titles, publishers, articles...) in order to make informed decisions about budget allocation and acquisition policy.

Usability: Customers want the ordered item anywhere, at any time, in a format that fits with the intended use (Dehlez et al. 2005). The usability and quality of the supplied items covers the whole range of information use: simple reading, archiving, dissemination (re-use), import in resource management systems, use in specific industrial or legal procedures (patent or new drug application) or for conferences, publications and educational issues, promotional or commercial use. One single format, one single quality level doesn't fit with all needs and document supply must be able to provide answers at least to most of them.

Reasonable pricing: Customers don't want chicken for free but are price-conscious. Document supply became a global and competitive market with public and corporate organisations. Pricing must reflect the reality of cost of information and added value (service quality, research and discovery...) but also the (public) funding of education, research and development. Processing costs should be kept low and transparent, especially administrative costs of invoicing and payment, and need explanation.

One may object that there are different categories of customers and that their needs may differ. This is certainly true. The INIST accounts of the last few years illustrate the wide range of national STI centres' document supply customers:

\begin{tabular}{|l|c|}
\hline \multicolumn{1}{|c|}{ Customer category } & Accounts \\
\hline Corporate companies & $32 \%$ \\
\hline Research organisations & $24 \%$ \\
\hline Higher Education & $16 \%$ \\
\hline Hospitals, medical centres \& clinics & $4 \%$ \\
\hline Information centres & $2 \%$ \\
\hline Individuals & $16 \%$ \\
\hline Others & $5 \%$ \\
\hline
\end{tabular}

Table 1: Breakdown of accounts per customer type (1999-2005)

All the same, even if their needs may vary in some ways, all customers are clear; they simply want the best service. And they know and say what they want (see for instance Watkins et al. 2002, Delaney 2003, Jackson 2004, Kasarab 2006 or Outsell 2006). So what is the impact on document supply, what should a modern service offer? 


\section{The use of new technologies in the front- and back-office}

The central concept of modern document supply shifts from the catalogue to the web based single customer access point. This access point may be directly linked to or even integrated into the customer's portal or management system (intranet). The front-office is moving away from the document supplier's own information system (see Infotrieve 2006).

The customer should be able to search for all available information through this single access point. The system should allow automatic consulting of the customer organisation's own print and electronic holdings, for instance by checking for ISSN, before searching in one or more suppliers' databases (with ordering functionalities), open archives, and publishers' or vendors' online collections (with pay-per-view facilities). Full-text linking can be provided through OpenURL systems such as Ex Libris's SFX that could also interface with online catalogues and interlibrary loan modules (Walker 2005).

While in the past special attention was paid to important collection databases and catalogues, modern document supply is built on powerful search engine technology. Federated search, clustering of results based on terminology resources, multilingual interfaces, customizable options and Web2.0 functionalities are on the agenda of the future development of a document supply system made for customers asking for more than simple document supply.

The front-office technology should not require specific software on the customer's desktop (Dehlez et al. 2005). Internet connection, standard browser, email program and PDF viewer should be all a customer need to use the document supply service.

Customers use Google, Yahoo, MSN (Live Search) or especially for STI, Google Scholar or Scirus. In order to keep pace with this search behaviour, document suppliers have started to integrate their records into one or more of these search engines. This strategy enhances the visibility of the suppliers services and enables the customers to keep their information discovery simple, to profit from very efficient technology, to obtain search results from an overwhelming number of global resources (including open archives and institutional repositories), and last but not least to choose the best way to get the material they want.

Customers should be able to order as they prefer - filling out an online order template, validating a pre-filled order form after a successful search, or using file transfer protocol or other, FTP-like protocols, especially in case of multiple or multi-source orders. Potential barriers between search and order should be kept as low as possible (see Detemple et al. 2005).

Most important in the back-office is software that enables customers and the LIS professionals to identify and locate the wanted information. Time and resource consuming, this functionality should be largely automated (Guadagno 2005). The system should be able to analyze the imported bibliographic data and give a quick feedback on incomplete or erroneous input. This analysis should include data from multiple sources - the document supplier's own database(s) and catalogue(s), bibliographic records from other libraries and information centres (remote supply), other databases (some suppliers are using the ISSN register), and metadata from open archives or publishers. If automatic identification fails, orders can be processed by experts but this manual search by LIS professionals in the back-office, even if vital for a high fill rate, should be kept to a strict minimum. 
The same principle applies to the processing of identified orders: the transfer to internal work stations (copy machines, scanners), to remote libraries or ILL networks or to online collections should be as automated as possible. The added value of the management system is the use of specific algorithms based on legal restrictions and empirical evidence with the pricing, quality and turnaround time of potential suppliers.

Except for ARIEL and digital fax, electronic document supply generally implies technical protection measures through a digital rights management system (Braid 2004). Most major document suppliers have implemented or have developed a DRM system that restricts or disables viewing, saving, printing, forwarding, copying and conversion of ordered digital item according to the publishers' requirements.

A final characteristic of modern document supply is the integration of software that supports operational and collaborative customer relationship management (CRM) and provides all functionalities of e-commerce, e.g. online buying and payment with credit cards, access to the current order status (claims), to the customer account and to meaningful statistics (reporting). The financial management system should also be able to export periodically copyright fee statistics to the right-owners (copyright agency, publishers).

\section{Resource sharing and networking}

Customers of document supply are looking for content depth and breadth. This requirement must not be misunderstood. The serials prices continue to increase well above the rate of inflation and the number of serials is still growing. No STI centre can cope in the long term with this evolution and maintain an exhaustive and representative scientific serials collection. Budget limits are only one reason, another is the changing nature of the demand. Because of the growing access to core collections through online subscriptions, customers' orders are shifting to the "long tail" of scientific publications, to highly specialised niche and marginal titles (Bador et al. 2007b). At INIST we observed that while the overall demand (items) decreased, more and more serials were requested (see figure 1). 


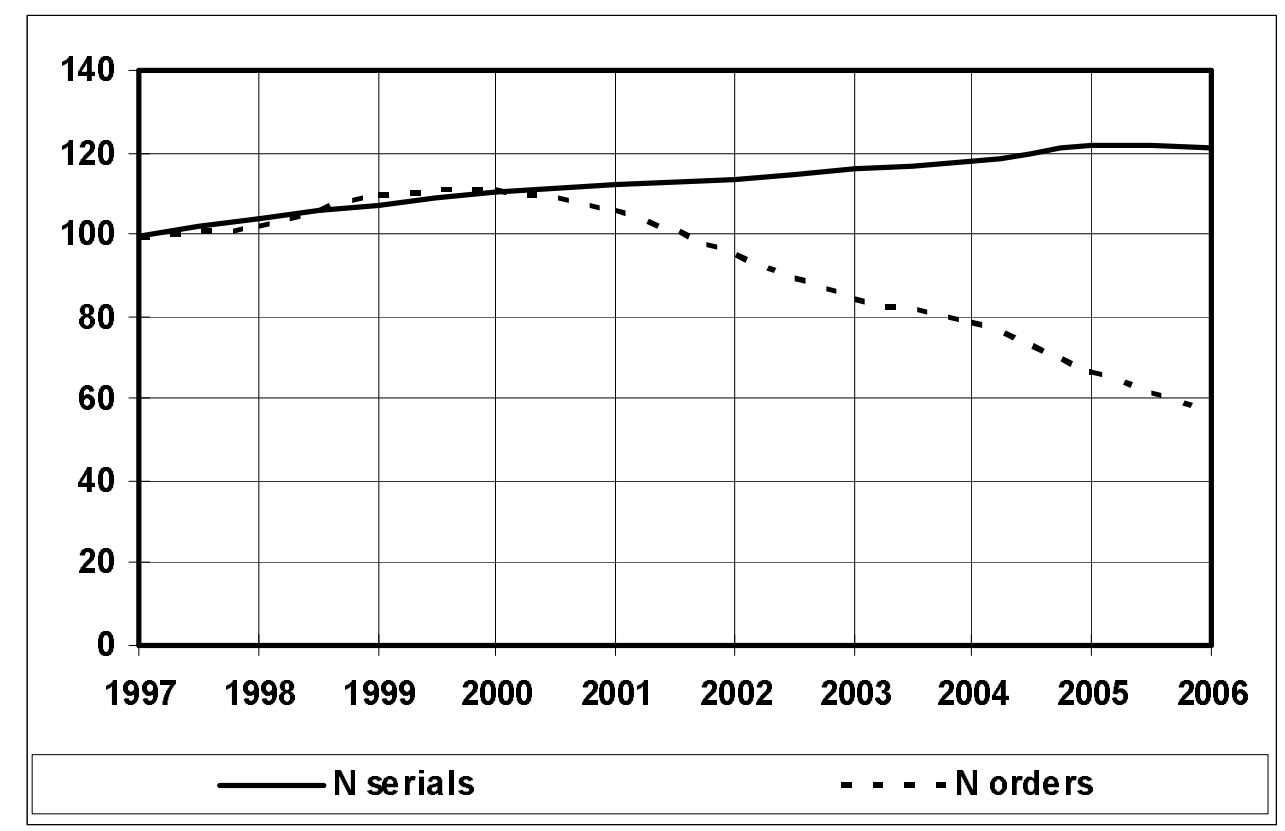

Figure 1: Document supply and requested serials (1997-2006, $1997 \mathrm{~N}=100)$

Ten years ago, the most requested items were published in journals with a high impact factor. Since then, the correlation between document supply and impact factor (citations) has decreased steadily (see Bador et al. 2007a). The distribution of item orders has become "flatter" (see figure 2).

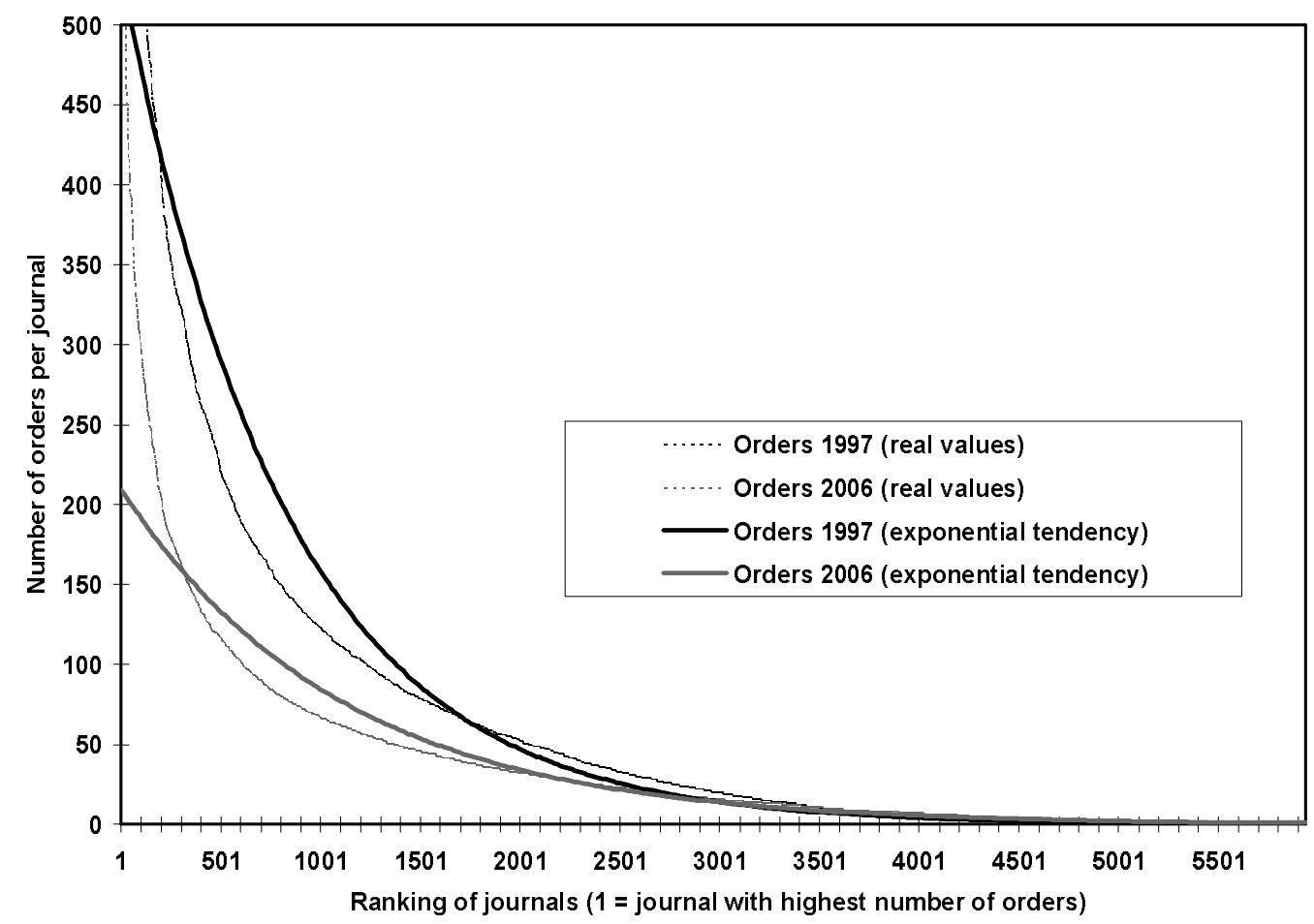

Figure 2: Distribution of item orders per journal (1997 and 2006) 
So far, more or less informed decisions on journal subscriptions or cancellations could be made using document delivery data (Ireland and Brown 2006). But no STI centre can reasonably define a long-term acquisition policy based on this "small level, long tail demand". Today we can distinguish three options for content development.

(a) Specialised collections: Instead of offering a wide range of information, STI centres can focus on well defined, clearly identifiable and specialised holdings. Shifting from content breadth to content depth, would mean the development of national "heritage" collections representative of national scientific production which in fact is the traditional role of national libraries. Alternatively, develop highly specialised collections in specific scientific domains, e.g. medicine, life sciences, social sciences and humanities and so on which is the traditional role of research libraries. Such a strategic decision implies consequent but limited investment but would not necessarily be consistent with a sustainable business model based on revenues from document supply, for the reasons mentioned above. Up to now, to our knowledge no important STI centre made this choice.

(b) Abandon collections: This second option is radical. STI centres can cancel all subscriptions, progressively or not, and invest the saved money into a powerful, network based information system which adds value and offers customer centred services. The quality of document supply would then entirely depend on the capacity of the STI centre to create a high quality network of remote suppliers and publishers and on the performance of technology, especially of the search engine. Because of the high costs of content acquisition and collection management which are about $50 \%$ of the overall document supply costs at INIST, the cancelling of subscriptions and the abandonment of in-house collections is probably the only option that allows a sustainable business model of document supply. The processing costs would also need to be kept low with a high degree of automation and minimal human resources which are another $35 \%$ of the document supply budget at INIST. As far as we know, only one major public supplier has adopted this strategy with success, the German FIZ Karlsruhe with its AutoDoc supply service ${ }^{4}$. Another international supplier, the Dutch NIWI, ceased its document supply activity shortly after the cancelling of subscriptions and was liquidated. It may be significant that the only commercial document supplier with a world-wide activity, Infotrieve, is based on this business model. It may be significant, too, that both, Infotrieve as well as the FIZ Karlsruhe AutoDoc service, are focussed on the corporate segment of the document supply market.

(c) Resource sharing and networking: Most major public document suppliers (TIB Hannover, CISTI, The British Library and others) adopt a mixed strategy based on three principles:

1. Conservation of more or less important and representative STI collections.

2. Development of document supply through resource sharing, by cooperation with remote back-up libraries and documentation services.

3. Networking based on agreements with a limited number of major STI centres and mainly STM publishers.

The objective of this mixed strategy is to maintain excellence in service quality and to optimize user satisfaction by high fill rates, rapid turnaround time, customized delivery options and acceptable direct costs.

\footnotetext{
${ }^{4}$ http://autodoc.fiz-karlsruhe.de/
} 
Nevertheless, this strategic is not without risk and impacts the document supply activity in several ways. Some aspects are listed below.

\section{Conservation of STI collections}

Once more, the case of INIST may illustrate the problem. The INIST serials holdings cover almost all scientific domains and are tend to be representative for international scientific production. Now, the acquisition costs of the different sub-collections vary significantly, and so does the document supply demand (see table 2).

\begin{tabular}{|l|c|c|c|}
\cline { 2 - 4 } \multicolumn{1}{c|}{} & Holdings & Budget & Document supply \\
\hline Social sciences and humanities & 33 & 6 & 3 \\
\hline Medical sciences, pharmacology & 21 & 19 & 36 \\
\hline Biology & 19 & 26 & 29 \\
\hline Civil engineering & 10 & 16 & 9 \\
\hline Physics, mathematics & 7 & 16 & 9 \\
\hline Chemistry & 6 & 12 & 11 \\
\hline Earth Sciences & 4 & 4 & 2 \\
\hline
\end{tabular}

Table 2: INIST serials holdings: domains, budget and supply (in \%)

If acquisition policy was only about "return on investment", INIST should develop its collections in medical sciences and pharmacology, biology and, to a lesser degree, chemistry for these domains generate 2-3 times more value than the other domains. Now this would be the end of a representative scientific collection and of the INIST interdisciplinary databases PASCAL (STM) and in particular FRANCIS (SSH). On the other hand, the price of academic medical serials increases more than in other domains. Policy is the art of compromise; and the result may be described with some irony as ... post-modern (Genoni and Jones 2004).

Another question is about digital collections. Like other national STI centres, INIST is not a campus-based library but negotiates e-only licences for national public research communities (CNRS portals ${ }^{5}$ ). The content of these licences is often richer than the print holdings. Including these digital libraries in the document supply offer is of obvious interest for the customers and requires special attention. Up till now, INIST made a clear distinction between agreements for its portals and for document supply. In the future, the development of the document supply and the customers' requests for "long tail journals" makes this separation unrealistic.

The preservation of digital collections and their use for document supply is a hot topic. Again, the ICSTI roundtable mentioned above revealed fundamental differences between publishers and national STI centres. Limited by restrictive licences, STI centres can't guarantee access to digital material for their scientific communities on the long term as they do for their print collections. Some libraries decided for this reason to reject whenever possible e-only subscriptions without print copies. Economically spoken, this decision doesn't make sense. But the problem is real, and publishers and STI centres have to (re)define a level playing field that satisfies the legitimate needs of science and education (access to digital information) and right-

\footnotetext{
${ }^{5}$ http://www.inist.fr/rubrique14.htm1
} 
owners (protection of rights and revenues) and that takes also into account the heavy investments by STI centres and libraries in infrastructure and information technology.

\section{Resource sharing}

As far as we know, the only library that contains all books is the infinite and cyclical Library of Babel described by Jorge Luis Borges in $1941^{6}$. Reality is different and characterised by distributed information and resource sharing. Even in our brave new Google world no scientist, no academic or engineer has access to all information he needs for research and education.

This is no surprise. All countries with significant R\&D activity invested in information infrastructure and public interlending: see for instance (Vaglio, 2007) or (Van Borm and Corthouts, 2003). Document supply networks based on national STI centres, research and academic libraries are part of this investment.

The serials crisis (Kyrillidou and Young, 2006) exacerbates the need for library cooperation. Increasing prices and limited funding require revision of acquisition policies and the development of interlibrary resource sharing. The following figure illustrates the evolution of document supply through resource sharing experienced by INIST:

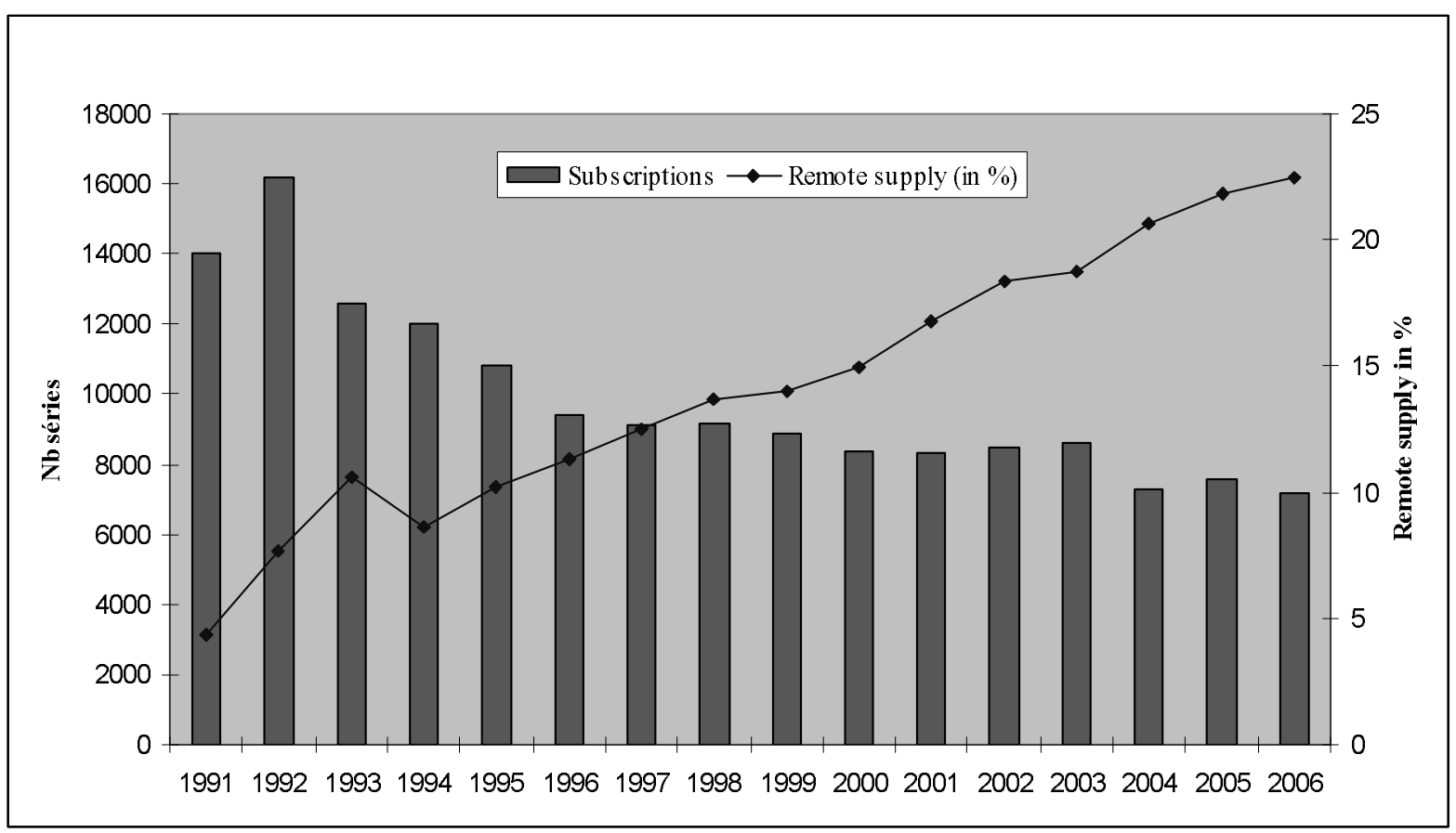

Figure 3: Evolution of print subscriptions and remote document supply (19912006)

This evolution has significant impacts on document supply:

\footnotetext{
${ }^{6}$ http://www.analitica.com/bitblioteca/jiborges/library babel.asp
} 
The business model of document supply changes; direct costs of document acquisition decreases because supplied items are acquired on demand, without subscription. The average cost of items supplied through resource sharing is about $20 \%$ lower than of items supplied from in-house holdings.

Nevertheless, at least on a national level public investment must guarantee acquisition and preservation (and access/supply) of scientific information, for instance through some large scientific, medical and social science and humanities libraries (the German $\mathrm{TIB}^{7}, \mathrm{ZBMed}^{8}$ or $\mathrm{BSB}^{9}$ ) or a greater number of specialised collections (the French CADIST ${ }^{10}$ ). Resource sharing comes to an end when all STI centres cancel their subscriptions. Simply speaking, resource sharing without investment sharing makes no sense. Even information services without in-house holdings like AutoDoc or Infotrieve partly depend on public funding through their agreements with major national STI centres and libraries.

Resource sharing challenges the quality of document supply, by increasing turnaround times and fill rates which are less tightly controlled than in a centralised system...Investment in new technologies and software, especially for resource discovery, search engines, linking and interconnection of catalogues and databases and automation of workflow is needed to satisfy the customers' need of a high standard service (Missingham and Moreno 2007, Wanner et al. 2007). Figure 4 illustrates the quality dilemma of resource sharing.

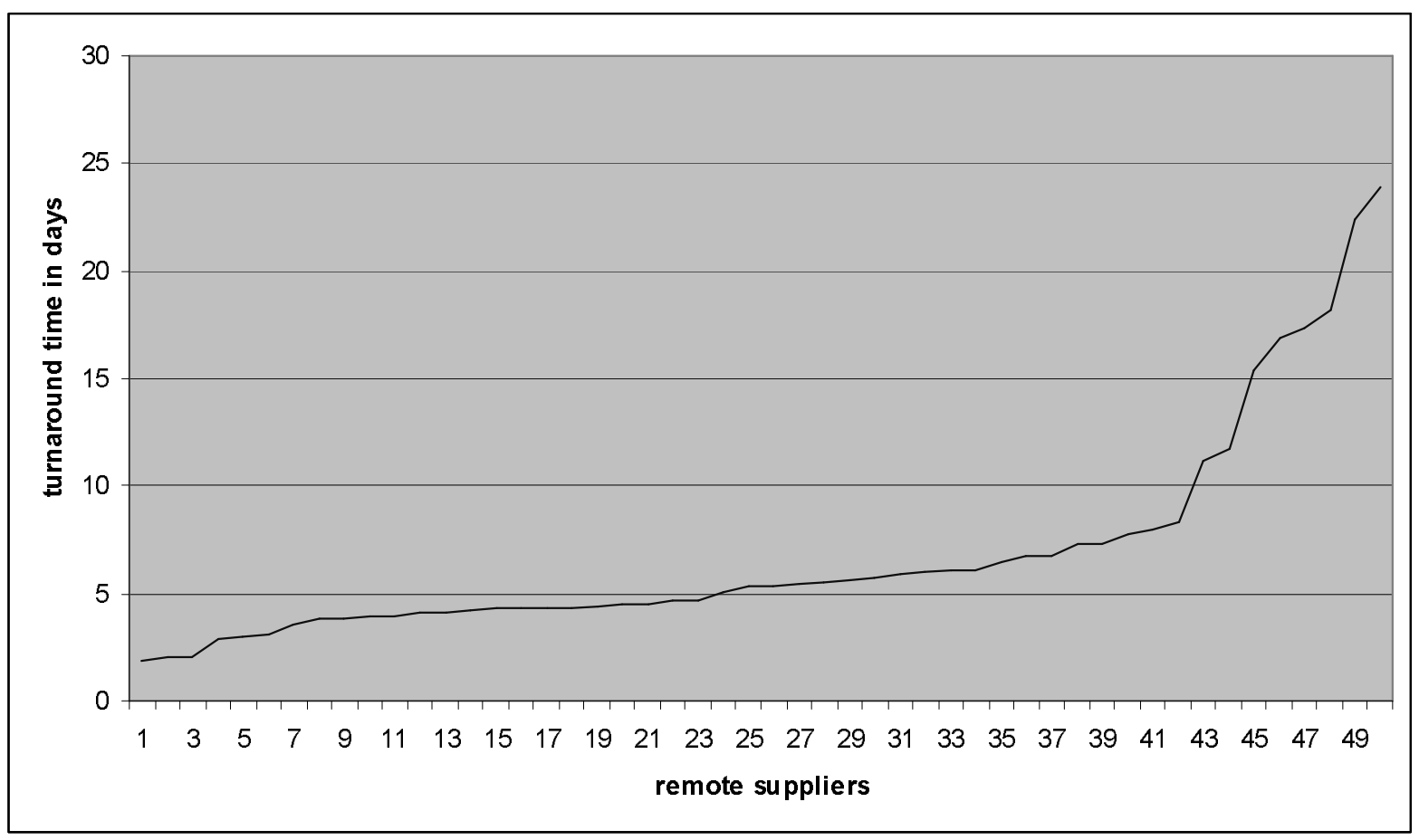

Figure 4: Average turnaround time of INIST's top 50 remote document suppliers (2006, in days)

\footnotetext{
${ }^{7}$ http://www.tib-hannover.de/

8 http://www.zbmed.de/

${ }^{9}$ http://www.bsb-muenchen.de/

${ }^{10}$ http://www.sup.adc.education.fr/bib/intro/cadist.htm
} 
About $10 \%$ of the requested items are delivered with an average turnaround time above 5 days. These delays are the price customers have to pay for a high fill rate. Our experience is that most customers accept these delays if they are informed about the reasons and the probable turnaround time.

Resource sharing tends to become a global affair. Laws on copyright and author's rights apply on national level. Differences between national laws and court decisions following lawsuits by the publishers' lobby set barriers to the international cooperation in document supply (Seadle 2007). The recent development of the German legislation on intellectual property provides a good (bad) example of the difficulties of international resource sharing. Managing document supply implies increasing legal expertise, and all major document suppliers are working today with excellent legal advisors to limit the risk for the institutions and their customers.

\section{Networking}

It is but one step from resource sharing to networking but this step is significant. Networking means remote document supply based on agreements with at least some basic clauses on service standards such as turnaround time, fill rate, delay of cancelling, copy formats, delivery mode, and price.

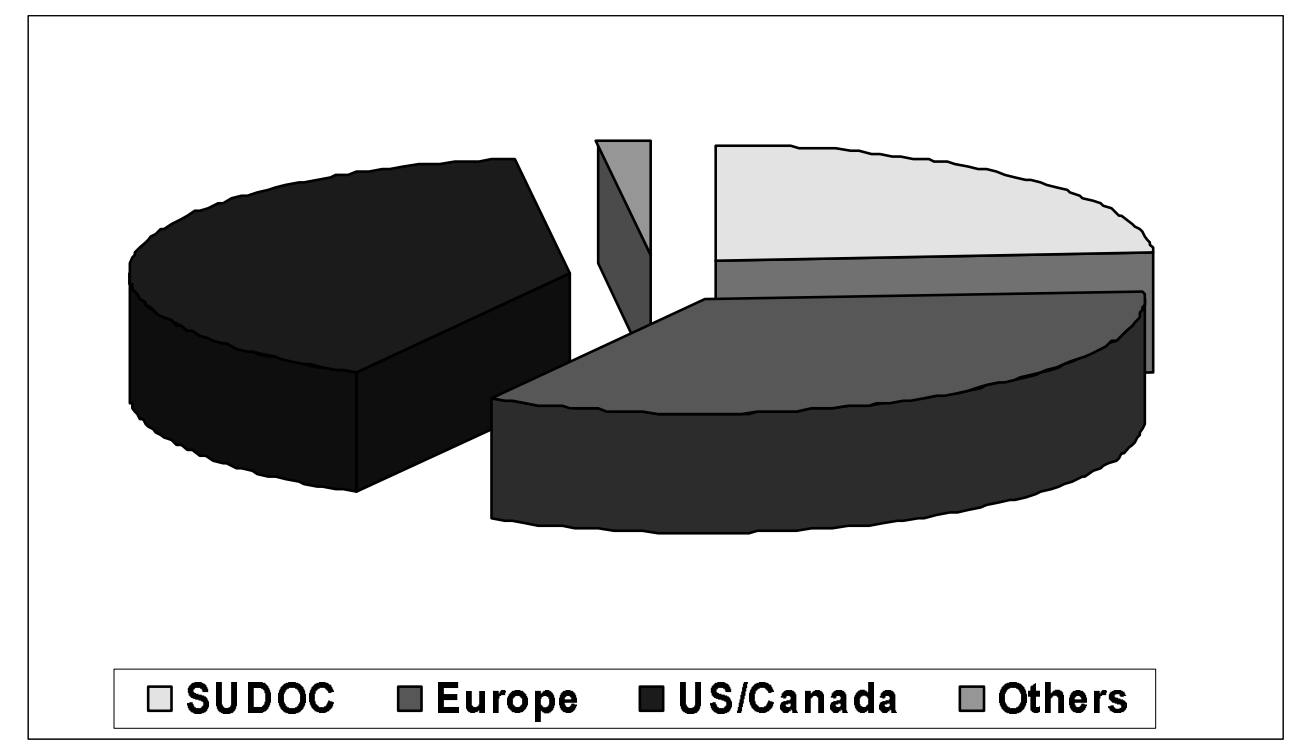

Figure 5: INIST top 50 remote document suppliers (2006)

$25 \%$ of the "remote" items are supplied through the French national academic ILL network SUDOC"1. The "basics" of this network are essentially a more or less harmonized price level and shared ILL software from OCLC-PICA (WinIBW) that allows automated processing of incoming orders and reporting (statistics). Nevertheless, there are no standards of delivery formats or modes, invoicing or turnaround times. Delays vary from 3 to 17 days, with an average delivery time of

${ }^{11}$ http://www.sudoc.abes.fr/ 
about 5 days. There is no formal agreement on document supply between the SUDOC libraries, only a licence for the use of the WinIBW software.

On an international level, INIST signed agreements with major European and American suppliers that cover $70 \%$ of its remote document supply. These agreements are subject to their specific legal environments, and there are no standards of order processing, delivery mode or formats, invoicing or reporting. Nevertheless, these agreements allow the turnaround times to be maintained at a reasonable level and at least in some cases, to facilitate the processing of orders by their direct and unmediated import. Another aspect of these agreements is the exchange of catalogues and serial files which simplifies the 'search' and locate' of requested items.

This cooperation is more than simple resource sharing; but is it really document supply networking? On a general level, the answer is yes. Not only because of the technical aspects but also because of its more informal, political or even strategic dimension: the coordination of the SUDOC libraries is realized through annual conferences and professional associations (ADBU ${ }^{12}$, AURA $^{13}$ ) and managed by the Montpellier ABES ${ }^{14}$ while the national STI centres work together in the ICSTI and IFLA framework and tend to develop a common "strategy of survival" of document supply in the digital world. Nevertheless, a lot of synchronization remains to be done.

\section{Negotiating copyright agreements with publishers}

Much has been written about the rapid development of digital libraries and about their impact on document supply. Instead of complaining, we should praise the growing access to scientific information as this is the underlying rationale of our supplier function.

As described above, customers of document supply want access to everything, they want it now, and they want it in usable formats. In other words, they want items from digital collections and archives, and they want electronic delivery (McKay, 2000).

\section{Items from digital collections}

A recent review of publishers' licences (Wiley, 2004) showed that the clauses on ILL and document supply vary significantly: some licences simply deny the use of digital content for ILL, others authorize it under condition, and sometimes the subscribing institutions are granted a right to make hard copies for ILL and document supply.

Some publishers fear the loss of control when supply is through a third party, that inappropriate use might result, as well as erosion of their subscription base (Braid, 2004). This is even though so far no discernible effect of document supply on journal subscriptions has been proven (Houle et al, 2003). Only experience with the article economy and empirical evidence from the emerging market may change this situation and allow real win-win agreements (McKay, 2000).

Business model: When negotiating electronic document supply most publishers, accept the pay-per-view approach where the STI centre is "just another selling point" for their own e-commerce. Based on statistics of the real demand, agreed copyright

\footnotetext{
${ }^{12}$ http://www.adbu.fr/

13 http://aura.bu.univ-paris5.fr/

${ }^{14}$ http://www.abes.fr/
} 
fees are transferred periodically to the publishers. However, some publishers, especially those interested in immediate and guaranteed cash-flow, link the pay-perview agreement to a content licence for the whole online collection or to a mix of print and online subscriptions, or to an agreement on non-cancellation of print subscriptions, or at least to an advance of a minimum number of down-loads.

Market: Most publishers consider the digital article economy as a global market where the same financial and technical conditions should apply to all customers without regard to their geographical origin, sticking to the logic of global ecommerce. This logic doesn't take into account specific national aspects such as author's rights or market price level, but only a minority of publishers accepts special conditions for article sales to national customers, in particular from the public sector.

Pricing: Again, we can distinguish different approaches that are apparently not related to real market situations but rather reflect the publishers' willingness, reluctance to "test" the new business model. Two third apply the same price to all categories of customers while one third agree a discount of $20-40 \%$ for the scientific communities from higher education and for public research. Elsevier and IOP are exceptions insofar they grant a special price (around $5 €$ ) for what they call "library privilege service", e.g. the translation of the traditional ILL into the article economy environment: electronic delivery from digital material between public funded libraries that have to print it out for the end-user. - The copyright fees vary widely from $7 €$ up to $40 €$, that is more than three times the usual market prices for the traditional supply of print copies. Are these prices realistic and in compliance with the market? As far as we know, only one publisher - Elsevier - has conducted a price sensitivity study and that was three years ago; it addressed especially the impact of lower prices on demand and regional, sectoral and domain effects but never communicated the results. Again, only empirical experience will (hopefully) inject some realism into the negotiations.

Metadata: To enhance the visibility of the new digital article service and to optimize the workflow from searching, ordering and accessing, STI centres need metadata from the digital collections. Metadata format and feed are part of the agreements on electronic document supply. Processing, reformatting (mapping), quality and followup of this metadata feed is a serious concern for STI centres and need substantial investment and re-engineering. In some cases, metadata feed has to be arranged not with the publisher but with the host of their digital collections (for instance, with Ingenta/Publishing Technology plc). Most publishers agree on free metadata feed, at least for the header information (title, author). Others apply specific prices for abstracts or for the entire records which means additional costs and finally higher prices for the end-user.

\section{Electronic delivery}

The discussion on electronic document supply sometimes makes an amalgam between digital material and mode of delivery. This is not justified: digital material can be delivered in print or print-like format (print copy by mail, fax), and print material can be delivered in digital text or image formats (PDF, JPEG, TIFF ...).

Some publishers are particularly unwilling to "give away" their digital collections for electronic document supply but nevertheless agree electronic delivery from existing print holdings. This business model has three implications: the STI centre has to 
maintain its print subscriptions and holdings, must (continue to) produce or buy elsewhere its own records and invest into scanning workstations and new workflows. All major document suppliers did so in the past, even if the financial impact was significant and the quality of the supplied material lower than the original publishers' files.

All publishers agree on one aspect: they ask for secure electronic delivery through DRM software in order to protect their resources from inappropriate use. One may wonder why most of them didn't implement DRM systems for their own pay-perview services but as a matter of fact, the DRM clause is part of all negotiations and STI centres and customers have no other choice than to accept this restriction, even if it is contrary to the customers' needs and more generally to the principle of fair use. It maybe that the recent abandonment of DRM restrictions in e-commerce by the music and multimedia industry will change this situation. Until now, the largest STM publishers, owned by investment funds, considered the article economy as their business, especially with those customers in their corporate sector business; they want to protect this business and are unwilling to discuss the topic.

Describing the pace of economic change, (McGrath, 2006) cited Marx. Let's add Hegel for whom the dialectical principle, the pull and push between forces that need and oppose each other constitutes the life and soul of historical process. In other words: inappropriate technical restrictions, prices too high have no future. It's just a matter of time.

\section{The future of the document supply}

Modern document supply is customer-centred, not service-centred. We described above what customers want. Here is a draft of what public document suppliers need:

Document suppliers need to improve knowledge of their customers. In some cases, they simply need to define who are their customers and for whom they work, and why.

They need to develop legal expertise to keep pace with fast changing laws, court decisions and licences and to guarantee 100\% legal compliance of their products.

They need to invest in search technology with customizable link and order options and they need to put the "order button" where their customers usually work.

They have to re-consider their service as e-commerce, not in order to compete with publishers, commercial suppliers and other vendors but because the future of public administration is digital.

They also need to improve functionalities of reporting (statistics, information about order and account status...) for the customer.

Document suppliers need to initiate, strengthen and accelerate resource sharing and networking. If they possess their own holdings, they should consider them as a part of the network, not as part of the document supply service.

They need to include more and more openly accessible material into their resource sharing and service offer (Morrison 2006), not to make money but to help their customers find what they want. 
They need to consider seriously the issue of evaluation, e.g. the quality label of supplied material.

Document suppliers need to invest in automation and if necessary, in re-engineering of workflow and organisation and in staff training.

They need to improve cost control and financial analysis if they want to maintain reasonable priced services for their communities.

And last not least, they need to shift from static information (FAQ, press releases and so on) to Web2.0 technologies that enhance direct interaction with the customers and augment "collective wisdom" on resources, terms and conditions, laws and STI market.

On a more general level, the members of IFLA Document Delivery and Resource Sharing Section revised their "Guidelines for Best Practices" last year". Their recommendations may be helpful to accompany the change of our concepts, tools and practices. The national STI centres have to take the lead. "Life punishes those who come too late" - Gorbachev's famous remark applies also to the information market. National STI centres have more time and stability than profit oriented information companies but they need to adjust rapidly to the digital world - even public administrations have to prove usefulness. This adjustment may also provide an appropriate answer for the next roundtable with publishers.

\footnotetext{
${ }^{15} \mathrm{http}: / /$ www.ifla.org/VI/2/p3/Guidelines_ILDD-en.htm
} 


\section{References}

Bador, P., Boukacem-Zeghmouri, C., Lafouge, T., Prost, H., Schöpfel, J. (2007a), “A cartographic analysis of the correlation between document supply and citations in pharmacology: a case study from INIST in France (part 2)". Interlending \& Document Supply, Vol.35, No.1, pp.7-14

Bador, P., Boukacem-Zeghmouri, C., Lafouge, T., Prost, H., Schöpfel, J. (2007b), "Analysis of the customers of document supply in pharmacology: a case study from INIST in France (part 3)". Interlending \& Document Supply, Vol.35, No.3.

Baker, D. (2003), "Document delivery: a new paradigm?" Interlending \& Document Supply, Vol.31, No.2, pp.104-110.

Beckett, C., Inger, S. (2006), Self-Archiving and Journal Subscriptions: Co-existence or Competition? An International Survey of Librarians' Preferences. London: Publishing Research Consortium.

Braid, A. (2004), "The use of a digital rights management system in a document supply service". Interlending \& Document Supply, Vol.32, No.3, pp.189-191.

Brown, D. (2003), "Is this the end of 'article economy'? A strategic review of document delivery". Interlending \& Document Supply, Vol.31, No.4, pp.253-263.

Dehlez, P., de Leeuwe, J., Dekker, R. (2005), “'Beyond the photocopy machine' revisited: document delivery on a digital library environment". Interlending \& Document Supply, Vol.33, No.3, pp.140-144.

Delaney, E.L. (2003), "GlaxoSmithKline Pharmaceuticals research and development: document delivery in a global corporate environment". Interlending \& Document Supply, Vol.31, No.1, pp.13-20.

Detemple, W., Herlan, G., Keil, U. (2005), "FIZ AutoDoc: a web-based full-text broker service". Interlending \& Document Supply, Vol.33, No.3, pp.150-154.

Genoni, P., Jones, M. (2004), "Collection coherence and digital abundance: enhancing the effectiveness of document supply". Interlending \& Document Supply, Vol.32, No.2, pp.109-116.

Guadagno, E. (2005), "Taking Interlibrary Loan and Document Delivery to New Frontiers Using Relais ILL". Journal of Interlibrary Loan, Document Delivery \& Electronic Reserve, Vol.15, No.4, pp.83-87.

Houle, L., Beckett, C., Costakos, C. (2003), "Just in Time vs. Just in Case: Examining the Benefits of Subsidized Unmediated Ordering (SUMO) vs. Journal Subscription". The Serials Librarian, Vol.44, No.3/4, pp.265-269.

Infotrieve (2006), Increasing the value of the library by optimizing document delivery. White Paper. Los Angeles: Infotrieve.

Ireland, M., Brown, B. (2006), "Using document delivery data for selecting medical titles in a large STM library: the experience of CISTI". Interlending \& Document Supply, Vol.34, No.1, pp.29-35.

Jackson, M. (2004), "Selecting the 'best' document delivery supplier". Interlending \& Document Supply, Vol.32, No.4, pp.242-243. 
Kasarab, H.V. (2006), "The impact of e-resources on document supply in a corporate pharmaceutical library: the experience of Novo Nordisk". Interlending \& Document Supply, Vol.34, No.3, pp.105-108.

Kyrillidou, M., Young, M. (2006), ARL Statistics 2004-05. Washington, D.C.: Association of Research Libraries.

Labriga, P. (2004), "Times of change for document delivery: a view from Infotrieve". Interlending \& Document Supply, Vol.32, No.1, pp.38-40.

McGrath, M. (2006), "Our digital world and the important influences on document supply". Interlending \& Document Supply, Vol.34, No.3, pp.171-176.

McKay, S.C. (2000), "E-Business for E-Journals: Article Pay-per-View". The Serials Librarian, Vol.38, No.1/2, pp.101-105.

Missingham, R., Moreno, M. (2007), "Australian resource sharing: did ILL benchmarking make a difference?" Interlending \& Document Supply, Vol.35, No.1, pp.21-27.

Morrison, H. (2006), "The Dramatic Growth of Open Access: Implications and Opportunities for Resource Sharing". Journal of Interlibrary Loan, Document Delivery \& Electronic Reserve, Vol.16, No.3, pp.95-107.

Outsell (2006), Information Management Best Practices: 2006 Product Satisfaction Scorecard - A Tool for Making Portfolio Choices. Vol.9, February 10, 2006. Burlingame CA, Outsell Inc.

Rowse, M. (2003), "Individual article supply: some strategic directions". Interlending \& Document Supply, Vol.31, No.2, pp.86-93.

Seadle, M. (2007), "Copyright in the networked world: international document delivery". Library Hi Tech, Vol.25, No.2, pp.298-304.

Vaglio, A. (2007), "Document supply in Italy: actual models and future perspectives". Interlending \& Document Supply, Vol.35, No.2, pp.115-118.

Van Borm, J., Corthouts, J. (2003), "Truly European: interlending and document supply in Belgium at the beginning of the twenty-first century". Interlending \& Document Supply, Vol.31, No.3, pp.162-168.

Walker, D. (2005), "Integrating Print Holdings into SFX". Journal of Interlibrary Loan, Document Delivery \& Electronic Reserve, Vol.15, No.3, pp.96-108.

Wanner, G., Beaubien, A., Jeske, M. (2007), "The rethinking resource-sharing initiative: a new development in the USA". Interlending \& Document Supply, Vol.35, No.2, pp.92-98.

Watkins, C., VanLeeuwen, D., Mexal, J.G. (2002), "Delivering Agricultural Documents: A Comparison of Suppliers". Journal of Agricultural \& Food Information, Vol.4, No.2, pp.81-94.

Wiley, L.N. (2004), "License to Deny? Publisher restrictions on document delivery from e-licensed journals". Interlending \& Document Supply, Vol.32, No.2, pp.94102. 
ILSD35.3 Gillet Schöpfel

\section{The authors}

Jacqueline Gillet is a librarian at INIST-CNRS in charge of negotiations with libraries and publishers and an expert on metadata and member of the IFLA committee on document delivery and resource sharing.

gillet@inist.fr

Joachim Schöpfel is head of the E-publishing and Document Supply Department at INIST-CNRS, and a lecturer on scientific information at the University of Nancy 2 and member of the research group "Document numérique \& Usages".

schopfel@inist.fr 